\title{
On a New Glucan from Corn Smut Galls*
}

\author{
Mitsuo HiUrA** \\ 樋浦光男：トゥモロコシ黒穂菌腫の新多糖について
}

Malformed smut galls in early stages of development obtained from axillary buds of mature corn stems were triturated with enough quantity of water, and filtered to get a clear solution. The filtrate was poured into twice its volume of $99 \%$ ethyl alcohol to result in a whitish precipitate. The crude precipitate was purified by repeating the same procedure, dehydrated with ether, and finally a white, tasteless and odorless powder was obtained. On microchemical analysis, nitrogen was not detected in the white powder, and the substance was different from starch, since iodine reaction was negative.

The white powder was completely hydrolyzed with $2 \mathrm{~N}$ sulfuric acid, and the hydrolyzate was submitted to paper chromatography. Only one spot corresponding to glucose was found. Glucose was further confirmed by acetylation of the hydrolyzate.

The negative specific rotation of the glucan, $[\alpha]_{D}^{20}=-40^{\circ}(\mathrm{c}=2$ in water) as well as its infrared spectra having a peak near $890 \mathrm{~cm}^{-1}$ indicated that a high proportion of $\beta$-glycosidic bonds was included in the glucan.

The glucan was hydrolyzed, under reflux, with $0.2 \mathrm{~N}$ sulfuric acid for six hours, fractionated by means of carbon-celite column and the syrup of each fraction was acetylated. In comparison of the acetylated with authentic samples, degradation products of the glucan were identified as glucose, gentiobiose, gentiotriose and gentiotetraose as well as laminaribiose and laminaritriose. These results indicated that the glucan consisted of a large number of $\beta-(1 \rightarrow 6)$ linkages, and a small number of $\beta-(1 \rightarrow 3)$ linkages.

The glucan was oxydized with sodium periodate. The formic acid consumed, given in moles per anhydrohexose unit, was 0.91 and the periodate consumed was 1.91 after 144 hours, respectively, suggesting that about $90 \%$ of the glucose residue might be joined by $\beta-(1 \rightarrow 6)$ linkages, and the remainder, by $\beta-(1 \rightarrow 3)$ linkages. So far, the compound is a new glucan and is tentatively termed as “zeagallan"1).

It seems very interesting to determine whether zeagallan is a product of the corn plant in response to the infection of the smut fungus, or merely a metabolic product of the pathogen. It was previously reported by the writer ${ }^{2}$ that a zeagallan-like polysaccharide was detected in the synthetic culture of the fungus. In order to obtain further information in this connection, some experiments were carried out to know whether zeagallan is contained in the smutspore itself or not.

Smutspores obtained from air-dried corn smut galls were sieved, and washed repeatedly with water. Forty grams of the spore were mixed with $200 \mathrm{ml}$ of distilled water, and autoclaved at 15 $1 \mathrm{~b}$ for thirty minutes, cooled and filtered. The filtrate was poured into $99 \%$ ethyl alcohol of three times of its volume to obtain a white precipitate. The yield of the precipitate was about $4.2 \%$ of

* 本研究の一部は 1967 年日本農芸化学東北地方大会で発表した。

** Hamamatsu Junior College of Hygiene and Nursing, Hamamatsu, Japan. 浜松衛生短期大学

1）樋浦光男 - 樋浦 誠 (1967). 農化, 41, No. 5, XXXIX (講演抄録).

2) Ochiai, S. and Hiura, M. (1968). Research Bull. Meisei Univ., 4: 1-7. 


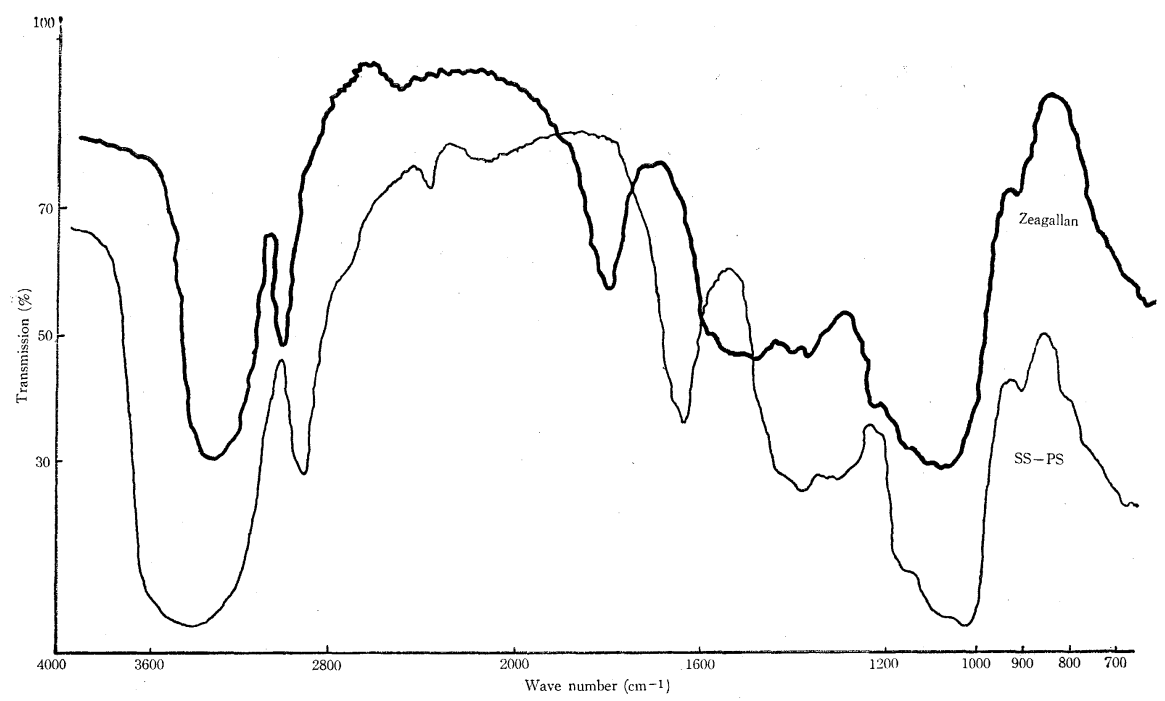

Fig. 1. Infrared absorption spectra (in $\mathrm{KBr}$ ) of zeagallan (S) and smutspore polysaccharide (SS-PS).

the smutspore weight. The infrared spectrum of the purified precipitate was very similar to that of zeagallan, though not exactly the same (Fig. 1). The result of the PPC test on acid hydrolyzates of the substance also revealed that it was a polysaccharide very similar to zeagallan in its main constituents.

The data suggest that zeagallan may be of the pathogen origin rather than the host response. Further studies are in progress.

\section{Acknowledgement}

The writer wishes to express his hearty thanks to Dr. Kazuo Matsuda, Department of Agricultural Chemistry, Tohoku University for his kind guidance and advice in the course of the present investigation. He is also grateful to Dr. Makoto Hiura, former president of the College of Dairy Agriculture, Nopporo, Hokkaido. 